\title{
Historical biogeography of Thyrsophorini psocids and description of a new neotropical species of Thyrsopsocopsis (Psocodea: Psocomorpha: Psocidae)
}

\author{
Cristian ROMÁN-PALACIOS ${ }^{1, *}$, Alfonso N. GARCÍA ALDRETE ${ }^{2} \&$ \\ Ranulfo GONZÁLEZ OBANDO ${ }^{3}$ \\ ${ }^{1,3}$ Departamento de Biología, Facultad de Ciencias Naturales y Exactas, Universidad del Valle, \\ Santiago de Cali, Colombia. \\ ${ }^{2}$ Departamento de Zoología, Instituto de Biología, Universidad Nacional Autónoma de México, \\ Apartado Postal 70-153, 04510 Mexico City, Mexico. \\ "Corresponding author: cromanpa94@gmail.com

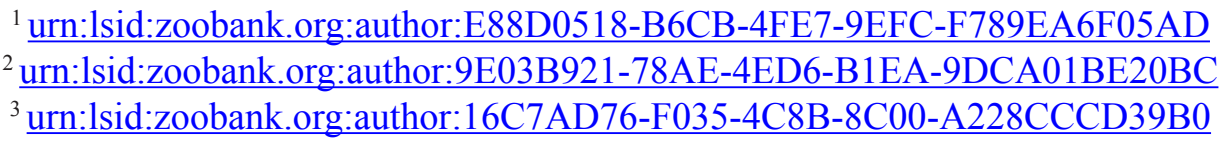

\begin{abstract}
When based on phylogenetic proposals, biogeographic historic narratives have a great interest for hypothesizing paths of origin of the current biodiversity. Among the many questions that remain unsolved about psocids, the distribution of Thyrsophorini represents still a remarkable enigma. This tribe had been considered as exclusively Neotropical, until the description of Thyrsopsocopsis thorntoni Mockford, 2004, from Vietnam. Three hypotheses have been proposed to explain this atypical distribution, recurring to dispersal, vicariance and morphological parallelism between lineages, but the lack of evidence has not allowed a unique support. Here, we describe a new Neotropical species of Thyrsopsocopsis, and also attempt to test the three biogeographical hypotheses in a phylogenetic context. In our analyses, the position of Cycetes (Cycetini) and Thyrsopsocopsis among Thyrsophorini psocids is well resolved, suggesting a dispersal event from the Neotropics for both genera.
\end{abstract}

Keywords. Historical biogeography, Psocids, dispersal, vicariance, parallelism.

Román-Palacios C., García Aldrete A.N. \& González Obando R. 2016. Historical biogeography of Thyrsophorini psocids and description of a new neotropical species of Thyrsopsocopsis (Psocodea: Psocomorpha: Psocidae). European Journal of Taxonomy 194: 1-16. http://dx.doi.org/10.5852/ejt.2016.194

\section{Introduction}

Psocidae is the largest and most diversified family of psocodeans (Lienhard \& Smithers 2002). Most of what has been published on the family consists of taxonomic papers, and little has been published on evolutionary or biogeographic aspects of it. The inclusion of molecular data on recent phylogenetic analyses has helped much to clarify the position of some genera and their status (Yoshizawa \& Johnson 2008, Yoshizawa et al. 2011), but its limited availability predisposes the family to a major morphologically oriented work (Li 2002). 
The classification of the various suprageneric lineages within Psocidae has varied through time, mainly due to the high morphological complexity (Lienhard 2008; Yoshizawa \& Johnson 2008). Currently, three subfamilies are recognized: Kaindipsocinae, Amphigerontiinae and Psocinae (Yoshizawa et al. 2011), the latter including five tribes among which Sigmatoneurini, Cycetini and Thyrsophorini are remarkable by their peculiar morphological plan (New 1978; Mockford 1992). Cycetini is characterized by a particular forewing venation along with the structure of female gonapophyses (Roesler 1940; Smithers 1972), but its position and systematic validity has not been tested within any phylogenetic scheme. The ambiguous status of this tribe within Psocinae has made impossible to establish a clear phylogenetic reference for discussing biogeographical or evolutionary aspects of other lineages as Thyrsophorini (Mockford 2004).

Thyrsophorini includes two major groups, previously referred as Cerastipsocinae and Thyrsophorinae (Yoshizawa \& Johnson 2008). This tribe, that includes the largest psocids (Mockford 2004, Smithers 1972), groups 15 widely distributed genera. Thyrsopsocus Enderlein, 1900, Thyrsophorus Burmeister, 1839, Dictyopsocus Enderlein, 1901, Poecilopsocus Roesler, 1940, Eremopsocus McLachlan, 1866, Cervopsocus New, 1978 and Ghesquierella Badonnel, 1949 are exclusively Neotropical lineages. Thyrsopsocopsis Mockford, 2004, along with Setopsocus Smithers \& Thornton, 1981, have been collected in the Oriental region; Cerastipsocus Kolbe, 1884 is the only Neartic-Neotropical genus. Neopsocus Kolbe, 1882, Longivalvus Li, 1993 and Sundapsocus Smithers, 1995 are distributed in the Palearctic. Finally, the specious Psococerastis Pearman, 1932 is widely distributed and Clematoscenea Enderlein, 1907 is restricted to the Oriental, Palearctic and Australasian regions (Lienhard \& Smithers 2002).

The genus Thyrsopsocopsis was erected by Mockford (2004) based on one male specimen collected in Vietnam and assigned to the subfamily Thyrsophorinae (currently Thyrsophorini), mainly by its morphological resemblance to the Neotropical Thyrsophorus. As Mockford (2004) pointed out, the establishment of the new genus within this exclusive Neotropical lineage represents "a difficult biogeographical problem", which can only be elucidated from an evolutionary context and by taking into account multiple aspects of the natural history of the tribe.

Several plausible explanations have been proposed to deal with the atypical distribution of this genus in relation to other Thyrsophorini. Mockford (2004) argues that this distribution could be consequence of (i) a modern dispersal to the Oriental region, as has been indicated for other psocids (Fig. 1A). This hypothesis implies a large specific richness of Thyrsopsocopsis in the Neotropics, and the sympatry of several (currently unknown) species along with T. thorntoni Mockford, 2004 in the same region. An alternative hypothesis suggests an (ii) ancient vicariance generated by the separation of the tropical lands (Fig. 1B). This event, which might have occurred near the Permian, establishes the possibility of the splitting of populations and subsequent speciation of the most recent common ancestor between Cycetini and Thyrsophorini. This approach implies Cycetini more diverse than Thyrsophorini in earlier times, following the centers of dispersal proposal. Finally, the possibility of (iii) parallel evolution between Neotropical and Oriental lineages, as a consequence of similar environmental conditions (Fig. 1C) has been also considered. In this paper we describe a new species of Thyrsopsocopsis from Brazil, propose a generic-level morphological phylogeny for Thyrsophorini, and discuss the systematics and biogeographical-evolutionary aspects of the tribe.

\section{Material and methods}

\section{Taxonomy}

The two Brazilian individuals available of Thyrsopsocopsis were dissected in $80 \%$ ethanol. The head, terminalia, right wings and legs were mounted on slides in Canada balsam. Measurements and photographs were taken using an AxioCam MRc5 mounted on an Axio zoom v16 microscope and 
stacked using the ZEN software (Zeiss Efficient Navigation). Color was recorded by placing the entire specimens under a microscope illuminated with cold white light at $40 \mathrm{X}$. The illustrations were processed in the vector graphics editor CorelDraw X7.
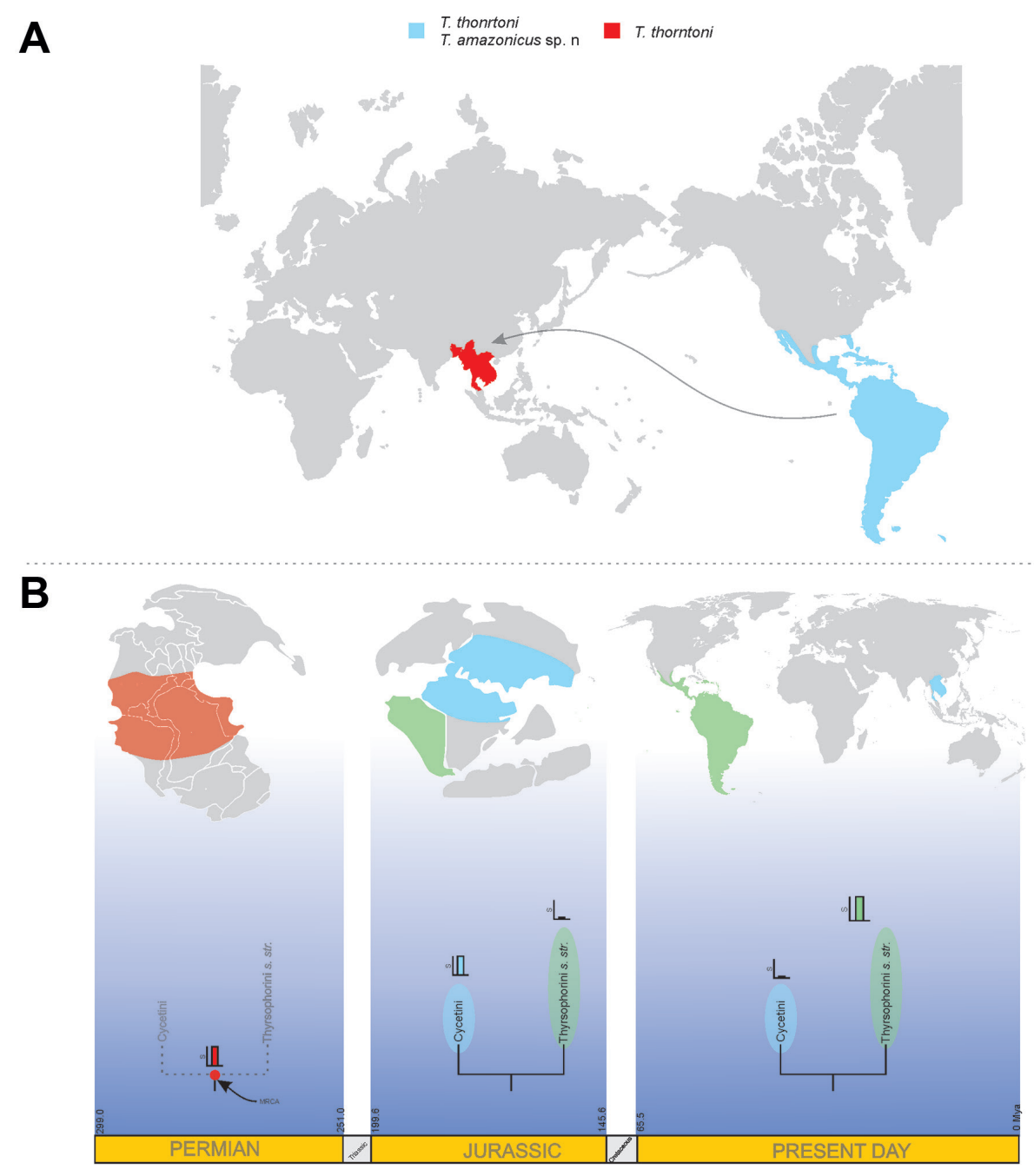

C

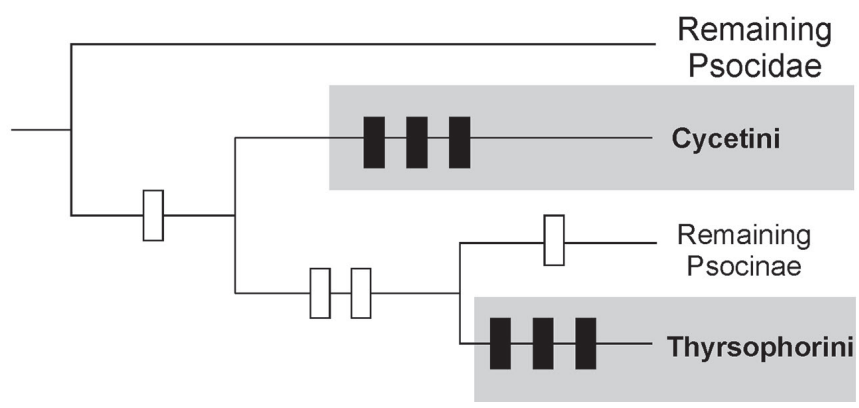

Fig. 1. Hypotheses for the current distribution of Thyrsophorini. A. Dispersal of Thyrsopsocopsis Mockford, 2004 from the Neotropics. B. Vicariance, as a consequence of the population split, occurred in the hypothesized most recent common ancestor of Thyrsophorini and Cycetini. C. Parallel evolution between the Neotropical and Asian lineages. 
Abbreviations for lengths of parts measured are as follows:

bp $\quad=$ basal prominence of mdp (see Mockford, 2004)

$\mathrm{D}, \mathrm{d}=$ antero-posterior and transverse diameters, respectively, of right compound eye, in dorsal view of head

$\mathrm{f} 1 \ldots \mathrm{fn}=$ flagellomeres $1 \ldots \mathrm{n}$ of right antenna

$\mathrm{FW}=$ right forewing

HW = right hindwing

IO = minimum distance between compound eyes

ldp = latero-distal processes of the hypandrium

mdp $=$ medio-distal processes of the hypandrium

$\mathrm{Mx} 4=$ fourth segment of right maxillary palpus

$\mathrm{pp} \quad=$ paired proximal processes of the hypandrium

The types will be deposited in the Coleçao de Invertebrados, Instituto Nacional de Pesquisas da Amazônia, Manaus, Amazonas, Brazil.

\section{Hypothesis testing}

\section{Systematics}

The matrix was constructed in MESQUITE 3.04 (Maddison \& Maddison 2008), resulting in 43 non-additive characters from 27 taxa(Appendices 1-2). Themorphological datawas analyzed underparsimony implemented in TNT (Tree Analysis Using New Technology, Goloboff et al. 2003) using a heuristic search (1000 replicates) of random addition sequence followed by TBR branch swapping. Characters were weighted using implied weighting with a concavity constant $(\mathrm{k})$ from 1 to 6 , selecting a $\mathrm{k}=3$. Node support was estimated using (i) relative non-parametric bootstrapping, (ii) symmetric resampling using 1000 replicates, and a heuristic search with a change probability of $33 \%$; these are reported as frequency differences between groups present and contradicted (GC), and (iii) Bremer support (BS; Bremer 1988, 1994). We selected multiple outgroups for testing the position of Cycetini and the monophyly of Thyrsophorini in accordance to Yoshizawa \& Johnson (2008): Amphigerontia Kolbe, 1880 (Amphigerontiinae), Elaphopsocus Roesler, 1940 (Amphigerontiinae), Elaphopsocoides Román-P., García Aldrete \& González-Obando, 2014 (Amphigerontiinae), Blastopsocus Roesler, 1943 (Amphigerontiinae), Ptycta Enderlein, 1925 (Psocinae), Trichadenotecnum Enderlein, 1909 (Psocinae), Atrichadenotecnum Yoshizawa, 1998 (Psocinae), Metylophorus Pearman, 1932 (Psocinae), Hyalopsocus Roesler, 1954 (Psocinae) and Sigmatoneura Enderlein, 1908 (Psocinae).

\section{Historical biogeography}

To include the biogeographic context in the phylogenetic interpretation of the Thyrsophorini, we used the ancestral reconstruction implemented in MESQUITE 3.04 (Maddison \& Maddison 2008) and RASP software (Yu et al. 2015). The former uses unweighted parsimony for tracing the character states through the tree and RASP evaluates the hypothesized ancestral ranges at each node in the tree by using a statistical framework, thus accounting for uncertainties both in phylogenetic inference and in biogeographic optimization (Piálek et al. 2012). The S-DIVA (Statistical Dispersal-Vicariance Analysis, modified from DIVA) and BBM (Bayesian Binary MCMC) in the package RASP were used to reconstruct the ancestral geographic distributions. The areas used and the distributions of the sampled species are given in Fig. 5A. The analysis uses distributions of contemporary species, which does not mean assuming similar continental configurations through time. The MCMC (Markov chains Monte Carlo) analyses in $\mathrm{BBM}$ were based on 50000 states, with a $10 \%$ burn-in generation. All biogeographical reconstructions were based in Maximum Likelihood (ML) topology, obtained from RAxMLGUI analyses (Silvestro \& Michalak 2011) by means of a MULTIGAMMA + Mk model, implementing 1000 replicates for the bootstrap support and selecting a single outgroup (Sigmatoneura), to limit the uncertainty that widely distributed and poorly known taxa would imply for the analyses; other taxa were pruned using the package APE (Paradis et al. 2004) in R software (R Core Team 2013). 


\title{
Morphological parallelism
}

The hypandrium was evaluated in order to account for the more variable structure in the two species of Thyrsopsocopsis, and test the morphological parallelism between Asian and Neotropical lineages. Therefore, it's assumed that morphological resemblance would suggest a narrow phylogenetic relation between taxa. The anatomical homology of the hypandrial morphological structure was assessed by external examination. Other characters commonly used for morphological phylogenetic analyses (e.g., phallosome or forewing morphology) are remarkably similar between the two species (compare Fig. 2A-F in this document with figures presented in Mockford, 2004).

\section{Results}

\section{Taxonomy}

\author{
Order Psocodea Hennig, 1966 \\ Suborder Psocomorpha Badonnel, 1951 \\ Family Psocidae Hagen, 1865 \\ Genus Thyrsopsocopsis Mockford, 2004 \\ Thyrsopsocopsis amazonicus sp. nov. \\ urn:lsid:zoobank.org:act:87C7E1C7-164C-461E-95D2-38F5B77B907D
}

Fig. 2A-F

\section{Diagnosis}

As in generic diagnosis (see Mockford 2004), plus the following: clunium bearing on the posterior margin a pair or heavily sclerotized lateral spines. Paraprocts with proximal handle. Hypandrium with $\mathrm{pp}, \mathrm{mbp}$ and ldp anteriorly directed (posteriorly directed in T. thorntoni); bp absent.

\section{Etymology}

The specific name refers to the nature of the area (Amazonian forest), where the types were collected.

\section{Type material}

\section{Holotype}

BRAZIL: $\widehat{\text { }}$, Amazonas, AM 010, Reserva Florestal Adolpho Ducke, Mixed light, 2 May 2002, J. Vidal.

\section{Paratype}

BRAZIL: 1 , same data as the holotype (INPA).

\section{Description (male)}

COLOR (in 70\% ethanol). Body light brown. Compound eyes black, ocelli hyaline. A broad dark brown band over most of the frontal suture, ending at the antennal fossae. Flagellum with f1 black, other flagellomeres brown. Pronotum and mesonotum with median black stripe. Legs brown. Fore- and hindwings with variable pigmentation and dark brown veins except for Cula and IA (white); pterostigma brown; a dark brown spot from discoidal cell to distal area. Hindwing without markings except basally.

Morphology. Compound eyes relatively small, the anterior borders not reaching the level of the convex vertex; antennae with first flagellomeres thickened and densely covered with setae. Forewing with elongate pterostigma; clunium bearing a pair of well-developed and heavily sclerotized lateral spines and with clunial shelf covering base of epiproct. Epiproct simple, rounded and semi-membranous. Posterior projection of paraprocts long and acuminate, inwardly directed; large sensory fields with many $(>100)$ trichobothria in basal rosettes. Hypandrium symmetrical, bearing short and acute median pp; mdp a 
massive bulb lacking bp; pp distally quadrangular and outwardly directed, bearing spines, spicules and setae over the surface; a heavily sclerotized and continuous band between pp and mdp. Phallosome closed, elongate, with a denticulate apical process, ending in a short tooth; endophallus laterally spinulose.

Measurements (in $\mu \mathrm{m}$ ). FW: 6600, HW: 4600, Mx4: 330, f1: 740, f2: 2320, f3: 109, IO: 970, D: 210, d: 350, IO/d: 4.61, PO: 1.6 .
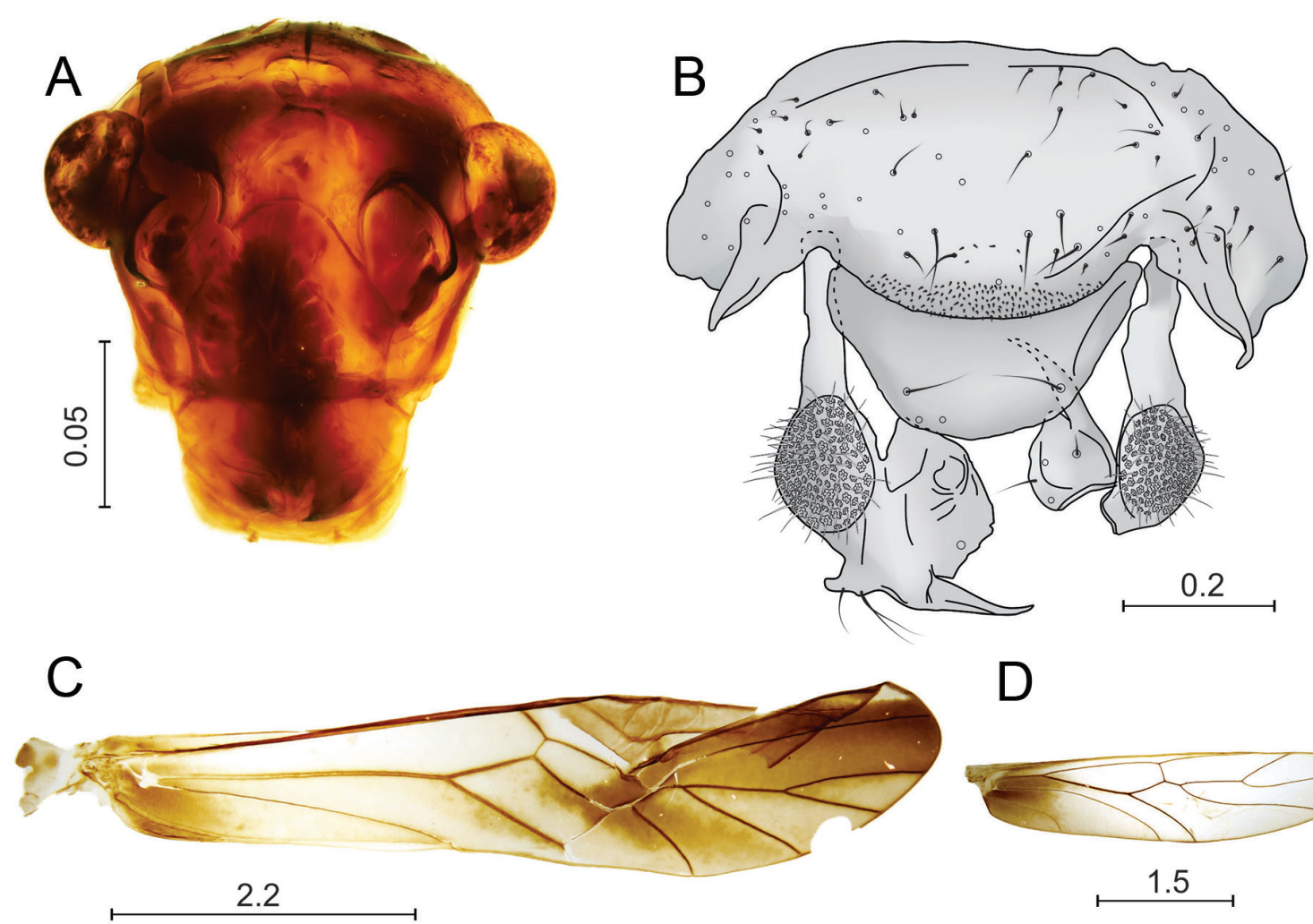

$\mathrm{D}$
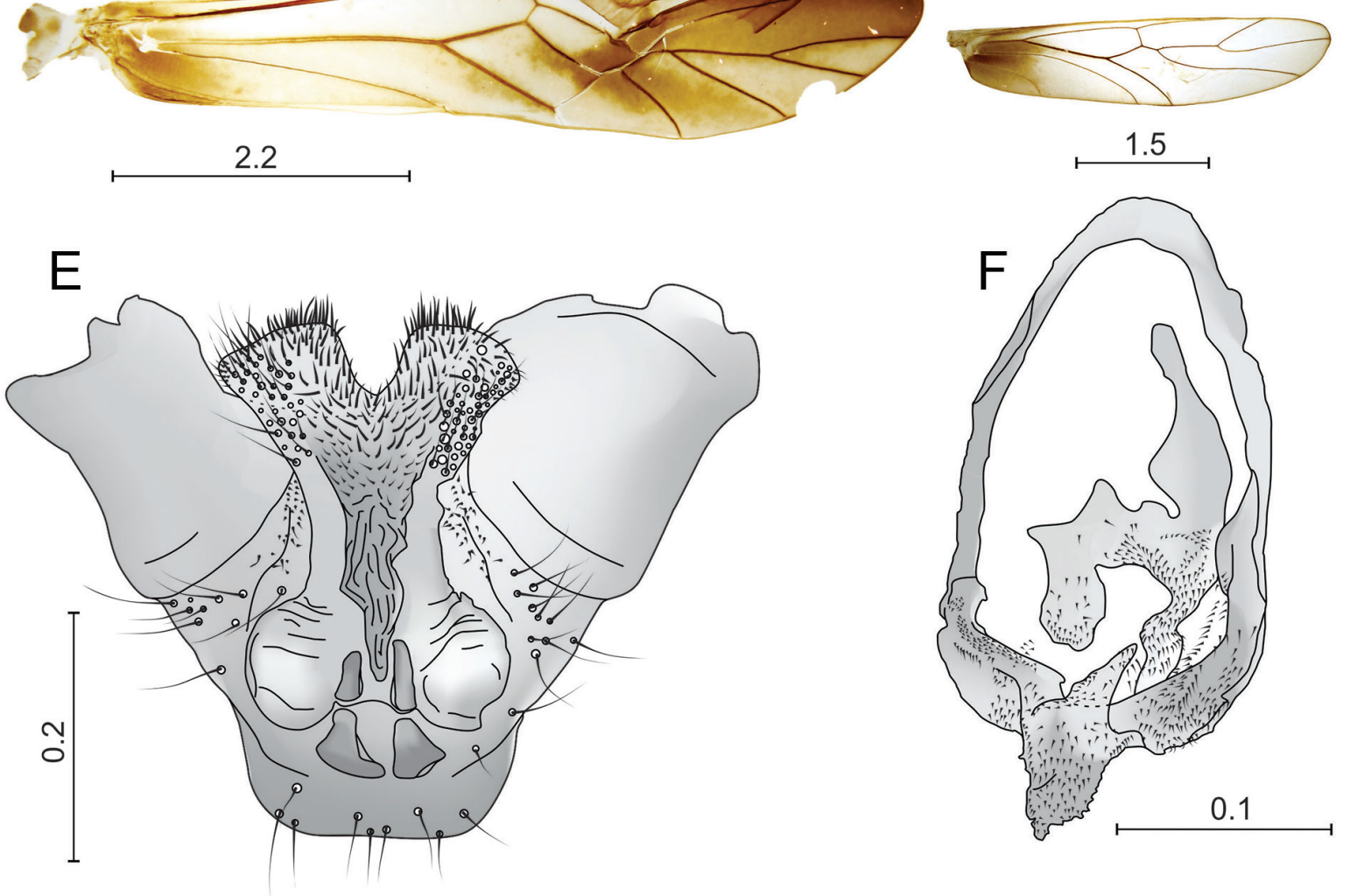

Fig. 2. Thyrsopsocopsis amazonicus sp. nov., §̂, holotype. A. Front view of head. B. Paraprocts, epiproct and clunium. C. Forewing. D. Hindwing. E. Phallosome. F. Hypandrium. Scales in mm. 


\section{Hypothesis testing}

\section{Systematics}

The relations among suprageneric groups were reconstructed and highly supported (Fig. 3). Sigmatoneurini represent the least derived tribe among thyrsophorinae-like lineages. Thyrsophorini was recovered as a monophyletic lineage, grouping genera previously assigned into separated two lineages (Cerastipsocinae

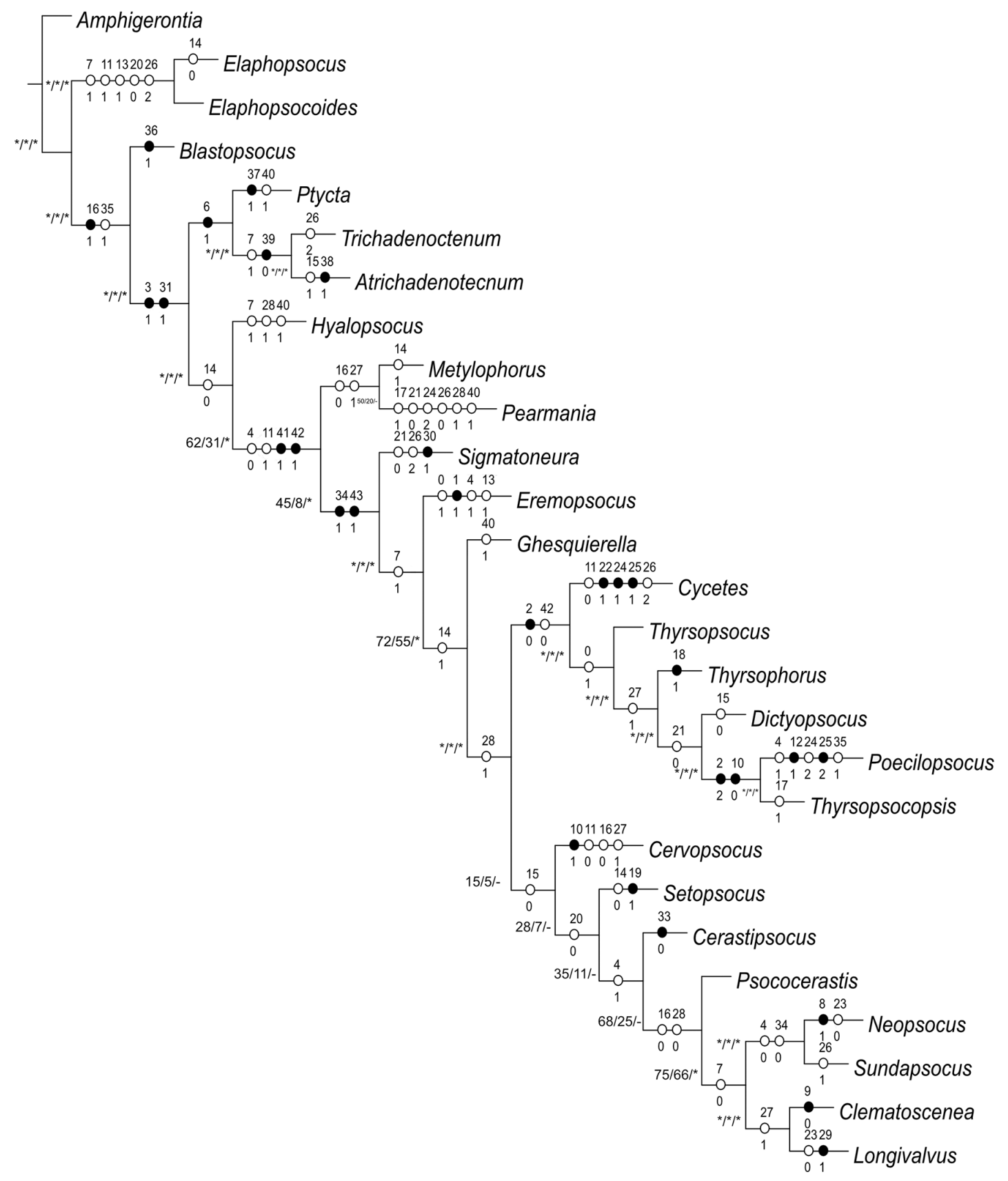

Fig. 3. Generic-level cladogram derived from parsimony analysis of the morphological dataset based on a heuristic search with 1000 replicates $(\mathrm{L}=127, \mathrm{CI}=40, \mathrm{Ri}=59)$, followed by TBR branch swapping, with character optimizations, symmetric resampling $(* 0.33)$, Bremmer support (*greater than 0.33 for the current dataset) and relative bootstrap ( $*$ greater than $70 \%$ ). Circles represent character optimizations: $\circ=$ unique changes; $\bullet=$ homoplasic characters. 
and Thyrsophorinae). The morphological phylogeny also indicated Cycetini (Cycetes Enderlein, 1907) merged within Thyrsophorini, suggesting a narrow relation between both lineages. The phylogenetic hypothesis supports two of the three hypotheses, but cannot differentiate between them: (i) a modern dispersal even for the Neotropical region and (ii) a vicariance event that involved the most recent common ancestor of both lineages. The parallelism proposal is not supported by the phylogenetic relationships recovered, because of the position of Cycetes within Thyrsophorini.

\section{Historical biogeography}

Historical reconstructions generated by parsimony, statistical parsimony and Bayesian algorithms, indicated similar and comparable tendencies in the biogeography of Thyrsophorini. The reconstruction of ancestral characters by unweighted parsimony indicated an ancestral Neotropical distribution for the tribe, and, consequently, the same distribution for the Cycetes ancestor (Fig. 4A). The genus Thyrsopsocopsis appeared as a lineage derived from a Neotropical ancestor. The current biogeographical evidence allows inferring the monophyly of a Palaearctic lineage, corresponding to the most recent common ancestor (MRCA), between Sundapsocus and Clematoscenea. The genus Psococerastis corresponds to a lineage with wider geographical distribution, but the analysis indicates the equivalent probability of an ancestral Neotropical or Palaearctic distribution. Statistical parsimony showed uncertainty in the ancestral distribution of most nodes in Thyrsophorini phylogeny (Fig. 4B). The MRCA between Thyrsopsocopsis and Poecilopsocus showed an exclusively Neotropical distribution.

Bayesian reconstruction of the historical biogeographic distribution of Thyrsophorini presented a major resolution in the internal nodes (Fig. 5). The ancestral distribution for Thyrsophorini resulted exclusively Neotropical, which agrees with the results of previous analyses. Thyrsopsocopsis represents a modern dispersal towards the Oriental region (T. thorntoni). The consensus analysis of the reconstructions obtained in S-DIVA and BBM (Fig. 6) showed a notable similarity in the results, and hence congruence between independent reconstructions. Cycetes may correspond to a dispersal from the Neotropics towards the Oriental-Australasian region, with a subsequent vicariance, resulting in the two species known for each region (C. collesi Smithers, 1977, C. thyrsophoroides Enderlein, 1907). An initial vicariance probably in the MRCA of Clematoscenea and Setopsocus generated the divergence between Neotropical and Palaearctic ancestors; the MRCA in Sundapsocus and Setopsocus corresponded to a dispersal from the Oriental region. Sundapsocus and Cervopsocus possibly diverged by vicariance among Neotropical and Palaearctic ancestral populations, similar to what occurred in the MRCA of Setopsocus and Clematoscenea. The principal biogeographic trend in Thyrsophorini has been one of dispersal from the Neotropics to the Oriental region (4 events), with the first region having the largest number of variance events within the area (9 events).

\section{Morphological parallelism}

This hypothesis proposes parallel morphologies in both lineages (Fig. 7), which can be contrasted from the more variable structure between the two species. The hypandrium of $T$. thorntoni bears a basal projection (bp), lacking in T. amazonicus sp. nov., but the background morphological plan of the hypandrium of both species is well conserved. Clunial projections found on males of T. amazonicus sp. nov. are absent in T. thorntoni. Finally, the phylogenetic position of Cycetini within Thyrsophorini does not support this hypothesis (see above).

\section{Discussion}

The former Thyrsophorini had been considered as a lineage restricted to the Neotropics, with a possible origin from Cycetini-like ancestors in the Oriental region (Mockford 2004). Since the inclusion of Cerastipsocini within Thyrsophorini (Yoshizawa \& Johnson 2008), the biogeographic heterogeneity has ceased to be a valid reference for the identification of these taxa, moreover, the description of 

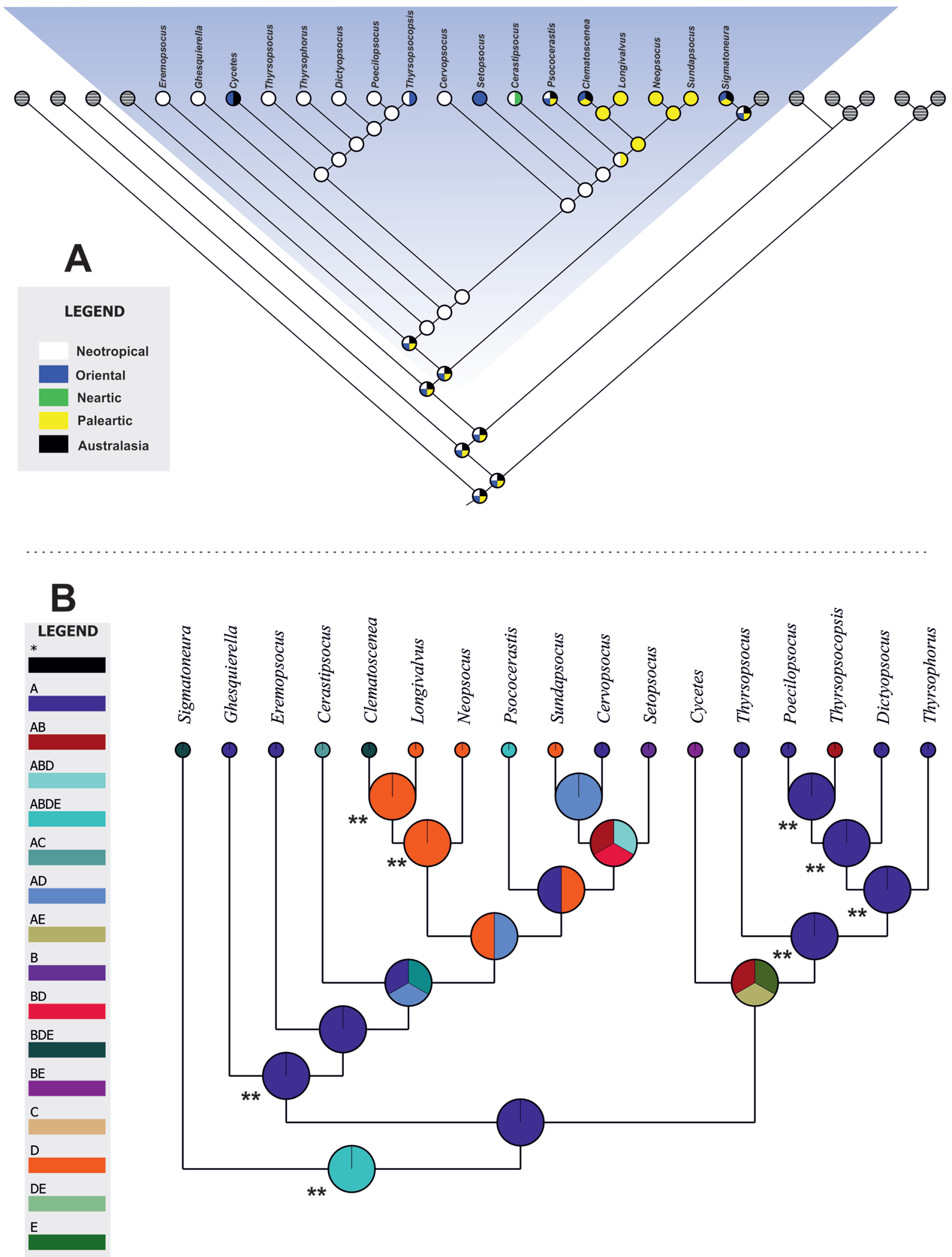

Fig. 4. Parsimony based reconstruction of Thyrsophorini historical biogeography. A. Parsimony based ancestral reconstruction implemented in Mesquite 3.04. B. S-DIVA biogeographical reconstruction. 


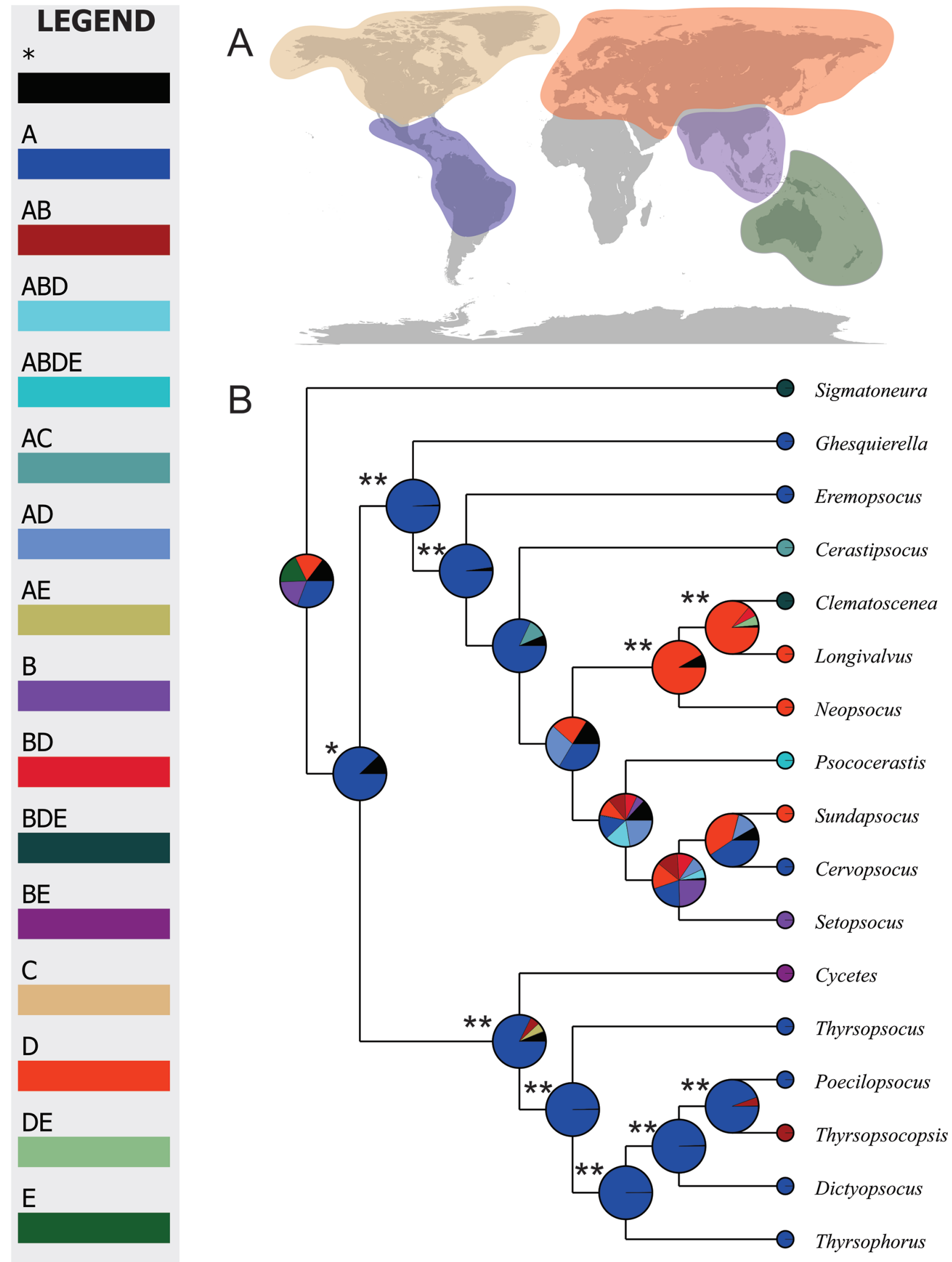

Fig. 5. Bayesian algorithms based reconstruction of the Thyrsophorini biogeography. A. Biogeographic regions considered in the analyses: Blue: Neotropics $(A)$, purple: Oriental $(B)$, Cream: Nearctic $(C)$, Orange: Paleartic $(D)$, Green: Australasia $(E)$. B. Reconstructed distribution using Bayesian Binary MCMC (BBM). 

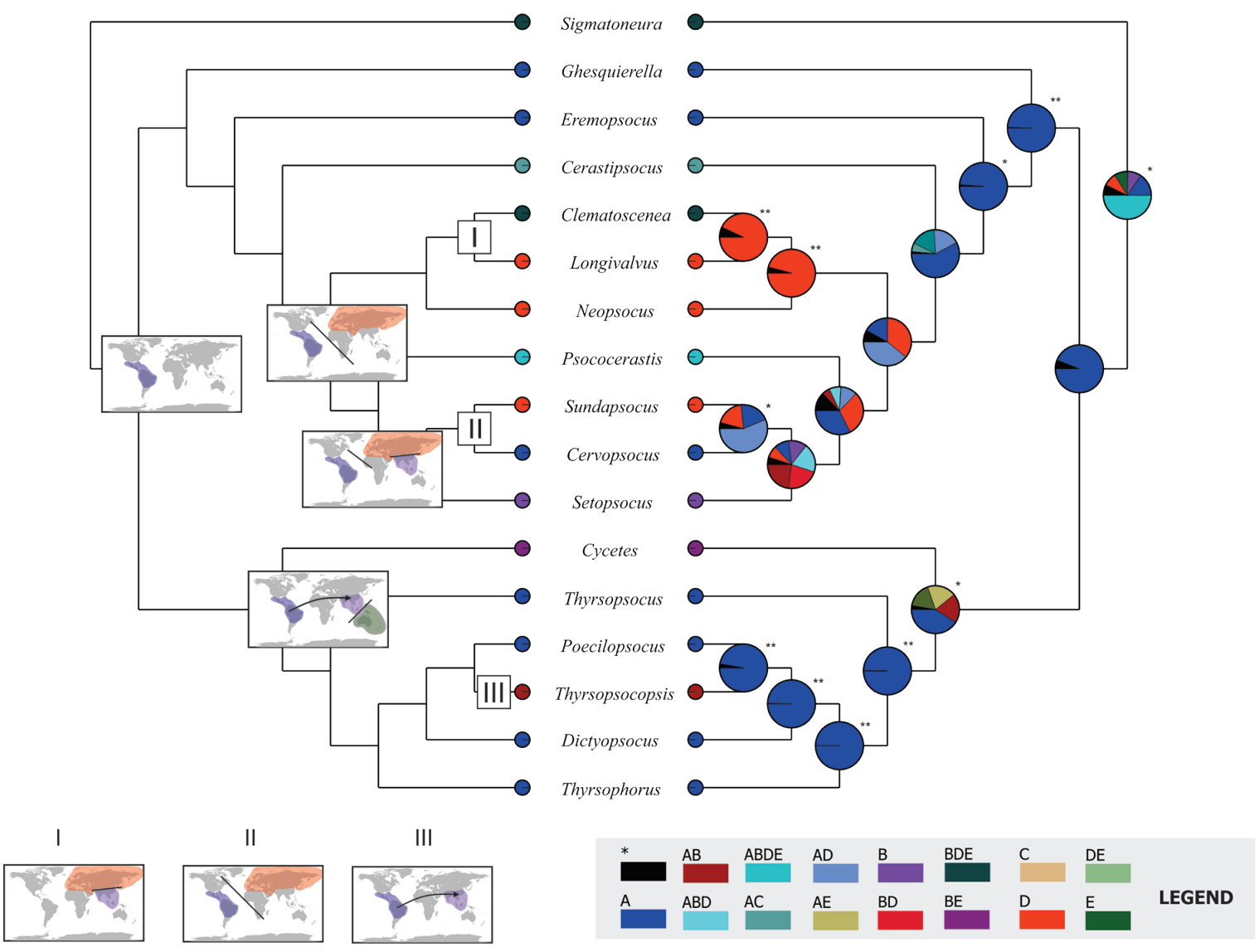

Fig. 6. Major biogeographical events occurred in Thyrsophorini (left) in accordance to the consensus reconstruction between BBM and S-DIVA analyses (right). Significant reconstructions indicated with *. I. Vicariance of the most recent common ancestor between Longivalvus Li, 1993 and Clematoscenea Enderlein, 1907. II. Allopatric speciation in the MRCA of Sundapsocus Smithers, 1995 and Cervopsocus New, 1978. III. Dispersal event occurred in Thyrsopsocopsis Mockford, 2004.

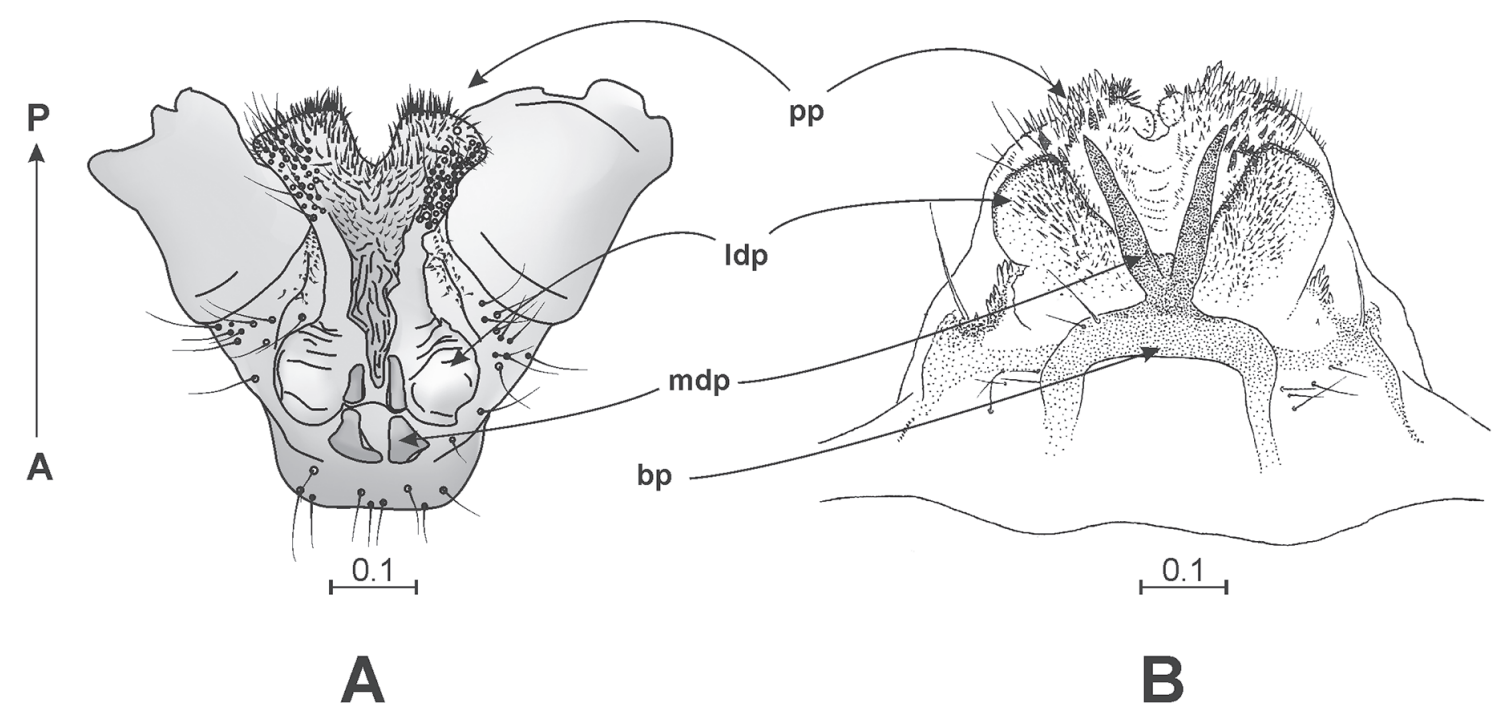

Fig. 7. Morphological homology of the hypandrial tubercles between the Neotropical and Oriental species. A. T. amazonicus sp. nov. B. T. thorntoni Mockford, 2004. Anterior -A and -P axis indicated on left. Scales in $\mathrm{mm}$. 
Thyrsopsocopsis shed doubts about the current knowledge on the evolutionary and biogeographic aspects of Thyrsophorini (Yoshizawa \& Johnson 2008). Thyrsopsocopsis thorntoni represented a change in the paradigm of the distribution of New World Thyrsophorini, allowing for hypothesizing different scenarios in the evolution of this clade (see Mockford 2004).

Cycetini has been given a tribal status for its remarkable morphological and biogeographic peculiarities with respect to the described thyrsophorines, but the description of the two known species of Cycetes was based on females, which do not provide an objective evidence for a correct assignation within Psocidae (New \& Lienhard 2007). The taxonomy of the family has been based mostly on male characters, and the male-female associations have been made on ecological and/or temporal evidences (e.g., Kaindipsocinae; Yoshizawa et al. 2011). Despite this, phylogenetic analyses carried out in the present work indicated that, although the wing and genital morphology of Cycetes are different from that usually found in Thyrsphorini, they represent generic apomorphies, brushing aside their consideration as tribal synapomorphies.

The systematic position of Cycetini in Thyrsophorini questions its tribal status. The phylogeny of Thyrsophorini agrees with the phylogenetic proposal made by Yoshizawa \& Johnson (2008), supporting the monophyly of Thyrsophorini, but resulted in several remarkable differences (e.g., compare Thyrsopsocus + Cerastipsocus in Yoshizawa \& Johnson 2008), which could be related to (i) the high morphological homoplasy found in Thyrsophorini morphology or (ii) a consequence of gene-tree based methods used in molecular analyses. The phylogenetic explanation made by Mockford (2004) is not congruent with that proposed in the current reconstruction. The author found support for the reciprocal monophyly of Cerastipsocinae and Thyrsophorinae, which was a clue for recognizing an Asiatic ancestry for the Neotropical thyrsophorines. The present biogeographic evidence and the position of Cycetini within Thyrsophorini support a Neotropical origin of this clade. Then, Cycetini represents an event of dispersal with a subsequent vicariance that resulted in the current two current species, which inhabit Australasian and Indomalayan regions.

Biogeographical reconstruction of the most recent common ancestor between Thyrsopsocopsis and Poecilopsocus suggest a possible dispersal event in Thyrsopsocopsis. This scenario increases its likelihood when considering biological (e.g., storms, drifting) or anthropic factors (e.g., commerce, transports) that could lead to the current distribution. Although the small degree of vagility of psocids is recognized by their anatomical fragility (Thornton 1964; Thornton \& Harrell 1965), their association with plants could be a key factor for dispersal, even at a transcontinental level. The description of Thyrsopsocopsis amazonicus sp. nov., and the richness of Thyrsophorini in the Neotropics makes the presence of Thyrsopsocopsis thorntoni in the same region quite plausible, but also suggests a higher Neotropical richness for the genus.

The morphology of Thyrsopsocopsis amazonicus sp. nov. shows a remarkable similarity with the Vietnamese species T. thorntoni. The pattern of wing venation, color, genital structure, and projections in paraprocts and hypandrium, allow for the assignment of the two species to the same genus (Mockford 2004). The morphological homology for the Neotropical and Asiatic lineages is also verified from anatomical evidence. The possibility of parallelism of the Thyrsopsocopsis lineages is falsified by (i) morphological homology and (ii) phylogenetic monophyly. Therefore, we conclude that the distribution of T. thorntoni corresponds to an event of modern dispersal, with a potential specific richness higher for Thyrsopsocopsis in the Neotropics. The tribal status of Cycetini is doubtful by its position within Thyrsophorini, but a nomenclatural act requires high experimental strictness for the objective establishment of the new clade.

\section{Acknowledments}

CRP and RGO are grateful to the Departamento de Biología, Facultad de Ciencias Naturales y Exactas, Vicerectoría de Investigaciones, Universidad del Valle, and GIE for research support. ANGA thanks Instituto de Biología, Universidad Nacional Autónoma de México, for continuous research support. The authors thank Dr. K. Yoshizawa and an anonymous reviewer for corrections and interesting discussions. 
ROMÁN-PALACIOS C. et al., Historical biogeography of Thyrsophorini

\section{References}

Bremer K. 1988. The limits of amino acid sequence data in angiosperm phylogenetic reconstruction. Evolution 42 (4): 795-803. http://dx.doi.org/10.2307/2408870

Bremer K. 1994. Branch support and tree stability. Cladistics 10 (3): 295-304. http://dx.doi. org/10.1111/j.1096-0031.1994.tb00179.x

Goloboff P.A., Farris J.S. \& Nixon K. 2003. TNT (Tree analysis using New Technology) (BETA) ver. 1.5. Published by the authors, Tucumán, Argentina.

Li F. 2002. Psocoptera of China. China Science and Technology Press, Beijing.

Lienhard C. 2008. Order Psocoptera. In: Harten A. van (ed.) Arthropod fauna of the United Arab Emirates. Vol. 1: 104-132. Dar Al Ummah Printing, Abu Dhabi.

Lienhard C. \& Smithers C. 2002. Psocoptera (Insecta): World catalogue and bibliography. Instrumenta Biodiversitatis V, Muséum d'histoire naturelle, Genève.

Maddison W.P. \& Maddison D.R. 2008. Mesquite: a modular system for evolutionary analysis. Available from: http://mesquiteproject.org [accessed 21 Aug. 2016]

Mockford E. 1992. Taxonomy of the Thyrsophorine barklice of Panama (Psocoptera: Psocidae: Thyrsophorinae). In: Quintero D. \& Aiello A. (eds) Insects of Panama and Mesoamerica: 257-270. Oxford University Press, Oxford.

Mockford E. 2004. A new genus and species of thyrsophorine psocids (Insecta: Psocoptera: Psocidae: Thyrsophorinae) from Vietnam. In: Garcia Aldrete A.N., Lienhard C. \& Mockford E. (eds) Thorntoniana: a commemorative volume for Ian W B Thornton (1926-2002): 151-158. Publicaciones Especiales 20, Instituto de Biología, Universidad Nacional Autonóma de México, México D.F.

New T. 1978. An appraisal of the Thyrsophorinae stat.nov. (Psocoptera, Psocidae) and of its constituent genera from the Neotropics. Systematic Entomology 3 (1): 35-49. http://dx.doi.org/10.1111/ j.1365-3113.1978.tb00386.x

New T. \& Lienhard C. 2007. The Psocoptera of Tropical South East Asia. Brill, Netherlands.

Paradis E., Claude J. \& Strimmer K. 2004. APE: Analyses of Phylogenetics and Evolution in R language. Bioinformatics 20: 289-290. http://dx.doi.org/10.1093/bioinformatics/btg412

Piálek L., Ríčan O., Casciotta J., Almirón A. \& Zrzavý J. 2012. Multilocus phylogeny of Crenicichla (Teleostei: Cichlidae), with biogeography of the C. lacustris group: species flocks as a model for sympatric speciation in rivers. Molecular Phylogenetics and Evolution 62 (1): 46-61. http://dx.doi. org/10.1016/j.ympev.2011.09.006

R Core Team. 2013. R: A Language and Environment for Statistical Computing. Available from: http:// www.r-project.org/ [accessed 25 Aug. 2016]

Roesler R.1940. Neue Copeognathen. Arbeiten über morphologische und taxonomische Entomologie aus Berlin-Dahlem 7: 236-244.

Silvestro D. \& Michalak I. 2011. raxmlGUI: a graphical front-end for RAxML. Organisms Diversity \& Evolution 12 (4): 335-337. http://dx.doi.org/10.1007/s13127-011-0056-0

Smithers C. 1972. The classification and phylogeny of the Psocoptera. Memoirs of the Australian Museum 14, Trustees of the Australian Museum, Sydney.

Thornton I.W.B. 1964. Air-borne Psocoptera trapped on ships and aircraft. Pacific Insects 6: 285-291. 
Thornton I.W.B. \& Harrell J.1965. Air-borne Psocoptera trapped on ships and aircraft, 2-Pacific ship trappings, 1963-64. Pacific Insects 7 (4): 700-702.

Yoshizawa K., Bess E. \& Johnson K. 2011. Kaindipsocinae is a sister taxon to the rest of Psocidae (Insecta: Psocodea: 'Psocoptera'). Invertebrate Systematics 25 (2): 81-90.

Yoshizawa K. \& Johnson K. 2008. Molecular systematics of the barklouse family Psocidae (Insecta: Psocodea: 'Psocoptera') and implications for morphological and behavioral evolution. MolecularPhylogenetics and Evolution 46 (2): 547-559. http://dx.doi.org/10.1016/j.ympev.2007.07.011

Yu Y., Harris A.J., Blair C. \& He X. 2015. RASP (Reconstruct Ancestral State in Phylogenies): a tool for historical biogeography. Molecular Phylogenetics and Evolution 87: 46-49. http://dx.doi. org/10.1016/j.ympev.2015.03.008

Manuscript received: 18 October 2015

Manuscript accepted: 13 January 2016

Published on: 6 May 2016

Topic editor: Koen Martens

Desk editor: Charlotte Thionois

Printed versions of all papers are also deposited in the libraries of the institutes that are members of the EJT consortium: Muséum national d'Histoire naturelle, Paris, France; Botanic Garden Meise, Belgium; Royal Museum for Central Africa, Tervuren, Belgium; Natural History Museum, London, United Kingdom; Royal Belgian Institute of Natural Sciences, Brussels, Belgium; Natural History Museum of Denmark, Copenhagen, Denmark. 
Appendix 1. Characters and character states.

1. First flagellomere incrassate: (0) Absent; (1) Present.

2. Second flagellomere incrassate: (0) Absent; (1) Present.

3. Veins R4+5 and M: (0) Fused; (1) Free; (2) Joined by a crossvein.

4. Phallosome distally: (0) Open; (1) Closed.

5. Distally closed phallosome morphology: (0) Oval; (1) Subtriangular.

6. Parameres basally: (0) Fused; (1) Free.

7. Chair-shaped epiproct: (0) Absent; (1) Present.

8. Distally ornamented phallosome: (0) Absent; (1) Present.

9. Glandular setae, especially on head: (0) Absent; (1) Present.

10. Cell M3 morphology: (0) Narrow; (1) Normal.

11. Pterostigmal morphology: (0) Elongate; (1) $\mathrm{L}=\mathrm{A}$; (2) $2 \mathrm{~L}>\mathrm{A}$.

12. Areola postica: (0) A $>$ L; (1) $A=L$.

13. Ramified veins in the central portion of forewing: (0) Absent; (1) Present.

14. Crossvein between areola postica and M: (0) Absent; (1) Present.

15. Hypandrium bearing processes: (0) Absent; (1) Present.

16. Number of processes on hypandrium: (0) One; (1) Two; (2) Three; (3) Four; (4) Six.

17. Distal denticles on hypandrium: (0) Absent; (1) Present.

18. Posterior margin of clunium: (0) Simple; (1) Ornamented.

19. Fore tibia expanded: (0) Absent; (1) Present.

20. Forewing bearing setae: (0) Absent; (1) Present.

21. R2+3 and R4+5 diverging at an angle of: (0) $60^{\circ}$; (1) $90^{\circ}$.

22. Distal margin of forewing: (0) Acute; (1) Rounded.

23. Ventral prolongation of V1: (0) Absent; (1) Present.

24. Short setae over v2: (0) Absent; (1) Present.

25. Forewing with Sc ending: (0) Free; (1) in costal vein; (2) in R vein.

26. Hindwing with Sc ending: (0) Free; (1) in costal vein; (2) in R vein.

27. Subgenital plate pigmentation: (0) T-shaped; (1) V-shaped; (2) Different.

28. Hypandrium: (0) Symmetrical; (1) Asymmetrical.

29. Gonapophyses with v3: (0) Normal; (1) Well developed.

30. R4+5 sigmoidal: (0) Absent; (1) Present.

31. Extension of the clunial shelf over the epiproct: (0) Absent; (1) Present.

32. Discal cell in longitudinal position: (0) Absent; (1) Present.

33. Male paraproct bearing a distal projection: (0) Absent; (1) Present.

34. Maxillary palpomere IV: (0) Large; (1) Short.

35. Rs-M: (0) Joined by a crossvein; (1) Fused.

36. Vein M+Cu1a: (0) Straight; (1) Sinuous.

37. Basal lobe on male paraproct: (0) Absent; (1) Present.

38. Opposite points over cell r: (0) Absent; (1) Present.

39. Triangular areola postica: (0) Present; (1) Absent.

40. Median strap on hypandrium: (0) Absent; (1) Present.

41. Gonapophyses with V2: (0) Slim; (1) Robust.

42. Nimphal aggregation: (0) Absent; (1) Present.

43. Forewing length: (0) Less than $4 \mathrm{~mm}$; (1) More than $4 \mathrm{~mm}$. 




